\title{
Proposal on Effect of Changes in Foreign Currency on Consolidating Financial Statements
}

\author{
Abeer Al-Zahrani \\ Department of Accounting \\ University of Jeddah, Saudi Arabia \\ Email: gogo5002 [AT] hotmail.com
}

\begin{abstract}
Knowing the effect that changes of foreign currency can have on the consolidation of financial statements is quite important to accountants dealing with firms that operate on a multi-national statement. This is because it will help such companies to be in a better position of ascertaining the negative impacts that may occur as a result of such changes and thus ensure that the consolidation of financial statements for their respective companies is done effectively and with fewer flaws.

This research proposal presents an introductory background of the research topic followed by the research questions that will be used in the study. The next part presents an outline of the research aims or the objectives and thus presents an insight of what this research proposal seeks to discuss. The significance of the study and the contributions that this research proposal will present in the field is discussed in this part. The next section if the theoretical frameworks and methods and this comprises of information regarding the numerous sources that will have to be consulted in the course of the study (Dyreng \& Markle, 2016). A research plan is the last part of the research proposal and it presents a timeframe of the numerous activities that will be undertaken at different periods of the research proposal and indicates that the whole research plan will take a period of 3 years. Lists of scholarly references which have been cited in the entire proposal are presented in references part.
\end{abstract}

Keywords---- Foreign, Currency, Statements, Effect

\section{INTRODUCTION}

A currency is defined as being money that exists in any form and which is in circulation being used as a medium of exchange in for of coins and banknotes. Generally, a currency is defined as being a system of money which is in common use for people of a given nation (Robinson, Henry, Pirie \& Broihahn, 2015). Foreign currency on the other hand is defined as being the currency of any given foreign nation which is deemed as being the authorized or legal medium of circulation and also a basis for keeping of financial records in such a specific country. That apart, a foreign currency implies to that which has been printed in a different nation and which may not be used in purchasing of goods and services in any other country unless the state of such a nation agrees in using it.

In the contemporary world, it is apparent that most of the people and business entities usually spread their business activities logically and globally and thus the need to use different currencies. However, it is important that people and organizations operating multinational business operations require operating using foreign currency (Ali, Akbar \& Ormrod, 2016). It is worth noting that the process of consolidating financial statements when such companies operate in different foreign currencies may be similar or different depending on the prevailing circumstances. For instance, in one aspect, one may be required to combine all the financial states that have been prepared using different currencies but yet still be required to follow and observe similar procedures for consolidation.

The changes of foreign currency can have an impact on the consolidation of financial statements in two major ways. One is that one will be required to ensure that there is elimination of both the share capital as well as the preacquisition profits of subsidiaries with the investment of the parent in such a subsidiary (McCauley et al. 2019). This implies that there will be need to recognize any form of goodwill as well as the non-controlling interests in such instances. Second is that one may be required to eliminate or abolish the intra-group transactions and balances which may include among others the unrealized profits on the intra-group sales as well as any of the dividends which have been paid up by subsidiaries to parent companies.

The fact that a country operates in different countries or nations across the world and uses different forms of foreign currency does not imply that it cannot effectively consolidate its financial statements. For example, for a company in the United Kingdom (UK), it is quite definite that most of the functional currency for such a company is mostly in the Great British Pounds (GBP). However, such a company may opt to prepare or make its financial statement in the United States Dollar (USD) or in the Euro (EUR) which are deemed as the presentation currencies (Aabo, Hansen $\&$ Muradoglu, 2015). There is always need for the relevant stakeholders to ensure that their financial statements are 
translated to presentation currencies when consolidating financial statements where foreign currency is involved. There is need to be careful and accurate when translating equity items in circumstances where foreign currencies are involves since any single mistake can cost the company a lot of finances.

\section{Research Questions}

- How does foreign currency affect the consolidation of financial statements?

- What are the negative impacts that arise as a result of changes of foreign currency on the consolidation of foreign accounts?

- What are the positive effects that arise as a result of changes of foreign currency on the consolidation of foreign accounts?

\section{Research Aims/Objectives of the Project}

- To investigate how foreign currency, affect the consolidation of financial statements.

- To find out the negative impacts that arises as a result of changes of foreign currency on the consolidation of foreign accounts.

- To evaluate the positive effects that arises as a result of changes of foreign currency on the consolidation of foreign accounts.

\section{SIGNIFICANCE/CONTRIBUTION TO THE DISCIPLINE}

This research study is quite helpful in the accounting and economic fields because it will help in helping stakeholders in such industries become aware that apples and pears cannot just be combined without making sense. This will help them known that before they begin carrying out consolidation procedures; there is need for them to ensure that the subsidiary financial accounts are translated to the presentation currency of the parent company in order to effectively consolidate the financial statement (Berrospide, Correa, Goldberg \& Niepmann, 2016). In addition to that, this research study will present viable information to stakeholders to become aware that despite the fact that a company may only have one functional currency, it is still capable of presenting its own financial statements in different presentations.

This research is quite significant to companies dealing in foreign exchange and the multinational companies doing their business operations from the host country. This is because it will help in depicting the fact that even though the functional currency may be highly dependent on the environment of a given firm as well as its operations, the manner in which it presents its currency is actually just a "matter of choice" (Rossi, Cohen, Caperchione \& Brusca, 2016).

It is quite unfortunate that there have been fewer studies and research endeavors that have aimed at ascertaining the effect of changes of foreign currency on the consolidation of financial statements (Perera \& Chand, 2015). This study will thus provide the much-needed information and knowledge to multinational companies and other companies who seek to expand their business operations beyond the border and who are bound to encounter dynamic changes in the use of foreign currency. This study will be of significant help because it will help stakeholders involved in foreign currency to be in a better position of consolidating their financial statements regardless of the country, they are in.

\section{THEORETICAL FRAMEWORKS AND METHODS}

This section deals with a discussion of the numerous sources that will have to be consulted in order to come up with viable information regarding the impacts that emanate as a result of changes on the foreign currency on the consolidation of financial statements. The researcher will consult numerous sources in coming up with the research study and mostly will be the secondary sources where the researcher will seek to use information from various secondary sources such as from books, journal articles, websites, and newspapers. The researcher will thus mostly and specifically use data and information that deals with the effects or impacts of foreign currency on the consolidation of data (Reid, 2018). To ensure that the information that will be used is current and updated, the researcher will ensure that only legitimate and authoritative sources are used in the research study. Such secondary sources will thus only those from this year to the last five years and this implies sources will be from the year 2016 to 2019.

The use of the latest sources in the research is quite essential because it will help in ensuring that latest trends and practices on the changes of foreign currency on consolidating if financial statements are captured in an effective manner (Avdjiev, McCauley \& Shin, 2016). Companies dealing with the exchange of foreign currency will also be consulted since they are in a better position of knowing the dynamic changes that occurs in foreign currency among different nations across the world.

\section{RESEARCH PLAN/TIMELINE}

There are numerous activities that will be undertaken during the process of the research study but however, the entire research study is expected to take a total of 3 years. 


\section{REFERENCES}

- Aabo, T., Hansen, M.A. and Muradoglu, Y.G., 2015. Foreign Debt Usage in Non-F inancial Firms: a Horse Race between Operating and Accounting Exposure Hedging. European Financial Management, 21(3), pp.590611.

- Ali, A., Akbar, S. and Ormrod, P., 2016, March. Impact of international financial reporting standards on the profit and equity of AIM listed companies in the UK. In Accounting Forum (Vol. 40, No. 1, pp. 45-62). Taylor \& Francis.

- Avdjiev, S., McCauley, R.N. and Shin, H.S., 2016. Breaking free of the triple coincidence in international finance. Economic Policy, 31(87), pp.409-451.

- $\quad$ Berrospide, J., Correa, R., Goldberg, L. and Niepmann, F., 2016. International banking and cross-border effects of regulation: lessons from the United States (No. w22645). National Bureau of Economic Research.

- Dyreng, S.D. and Markle, K.S., 2016. The effect of financial constraints on income shifting by US multinationals. The Accounting Review, 91(6), pp.1601-1627.

- McCauley, R.N., Bénétrix, A.S., McGuire, P.M. and von Peter, G., 2019. Financial deglobalisation in banking?. Journal of International Money and Finance, 94, pp.116-131.

- $\quad$ Perera, D. and Chand, P., 2015. Issues in the adoption of international financial reporting standards (IFRS) for small and medium-sized enterprises (SMES). Advances in accounting, 31(1), pp.165-178.

- $\quad$ Reid, W., 2018. The meaning of company accounts. Routledge.

- $\quad$ Robinson, T.R., Henry, E., Pirie, W.L. and Broihahn, M.A., 2015. International financial statement analysis. John Wiley \& Sons.

- $\quad$ Rossi, F.M., Cohen, S., Caperchione, E. and Brusca, I., 2016. Harmonizing public sector accounting in Europe: thinking out of the box. Public Money \& Management, 36(3), pp.189-196. 